\title{
THE MAIN DEMOGRAPHICS CHANGES IN THE POPULATION OF BACĂU COUNTY AT THE LAST CENSUS
}

\author{
Eugenia Harja \\ "Vasile Alecsandri" University of Bacău \\ eugenia.harja@ub.ro
}

\begin{abstract}
Livestock population and its structure is the starting point for all development strategies at both micro and macro level, reason for which accurate knowledge of it is one of the main objectives of official statistics in each state. The analysis aims to highlight the major changes produced after the 90s in terms of population of Bacău county and its structure, with time effects on economic and social activity. Both the 2002 and 2011 census, Bacău was top of the list with an absolute decrease of the population. This was a concern as it has emerged over time as a stable phenomenon. The main reason for the decrease was due to external migration of the population and secondly because of the internal migration flows of population moving towards large economic centers in the country and abroad that attract labor. As most of the migrants are young and active age groups, this phenomena has led to an aging population and to imbalances that can be observed in the age pyramid, with negative effects becoming larger in the future.
\end{abstract}

\section{Keywords}

Census; stable population; demographic aging

\section{JEL Classification}

$\mathrm{C} 10 ; \mathrm{J} 10 ; \mathrm{J} 11$

\section{The importance of knowing the population and methodological notes}

Stable population in both actual and structured after various features, underpins all marketing research, development strategies, be it macroeconomic level, or company strategies. The population is the one that provides labor resources but also that consumes work results, therefore it cannot be excluded from any study, and hence the importance of knowing it closely to the reality. Census of the population is in this regard the largest statistical research in demography, providing a large number of data on the population that there cannot be found in current statistical surveys. The census surprises aspects of both internal and external migration without documentation, therefore non-existent in the administrative sources. In general, the stable population, according to the methodology, includes all persons living at the time of the census for at least one year, or that came to town with the intention of staying for at least one year, whether or not they had legal documents, whether they were Romanian or foreign citizens.

\section{Stable population dynamics at the latest census}

The population of Bacău County recorded an upward trend reaching its peak at the 1992 census, when it was about 1,8 times higher than in 1948. After this year, the evolution changed in a significant negative trend. Privatization of large industrial 
enterprises in the county, which attracted most of the labor force, significant restructures of them that eventually dissolved many, led to a massive internal migration, but especially foreign. Bacău was the county facing the largest loss of actual people in the last two censuses. The stable population at the last census was very close to the one in year ' 66 .

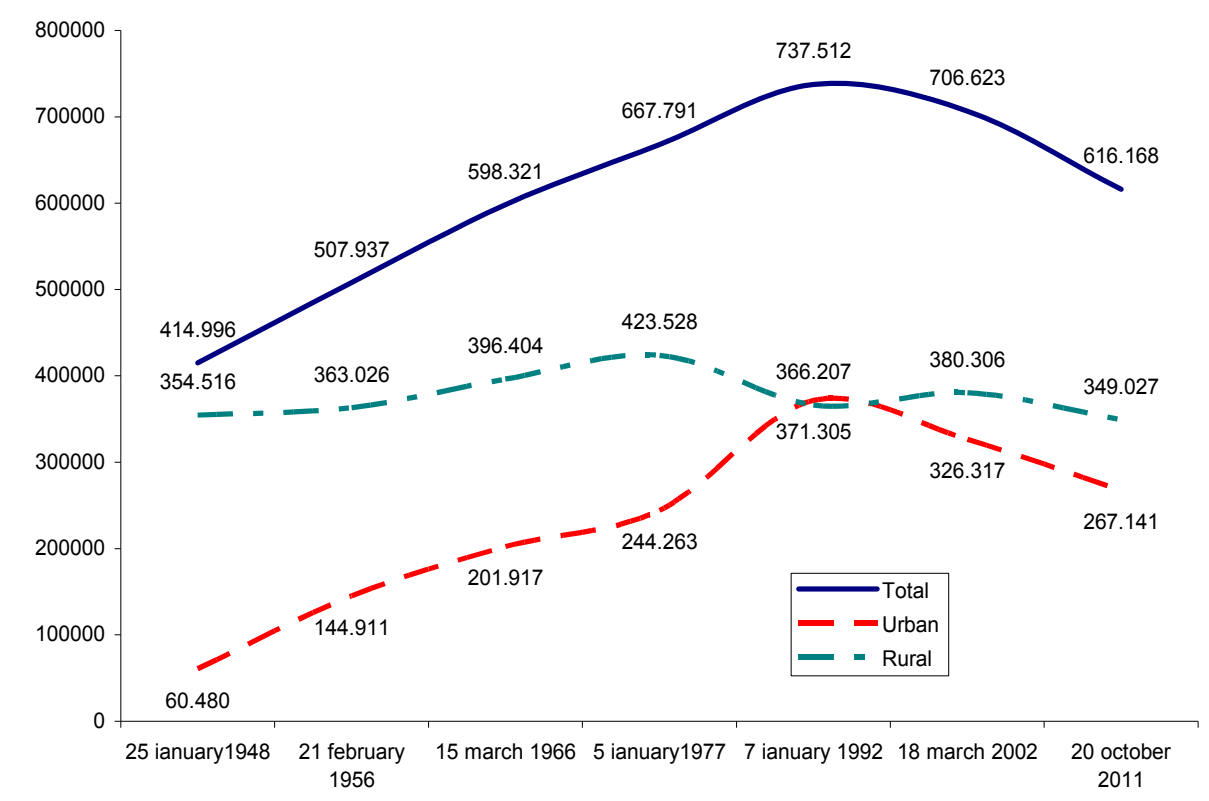

Figure 1 Evolution of the stable population of Bacău county in total and average at the last 7

Source: own calculations based on data from the Statistics Institute of Bacău County

If at country level there were lost 1,56 million people, Bacău County has lost 90.455 people, with $-12,8 \%$ compared to the 2002 census, being the 9 th district in terms of relative decrease. Because of this great decrease, the county's place in the hierarchy of the country was changed from 6 in 1992 and 2011, to number 9, after Bucharest and counties like: Iaşi, Prahova, Cluj, Constanţa, Timiş, Dolj and Suceava.

From the northeast region Bacău was surpassed by Suceava, which decreased, but to a much lesser extent. This way, the share of total population in the region has changed, from $3,26 \%$ to $3,06 \%$ in the last census.

If rural stable population fluctuated somewhat around 370 thousand people, urban population has experienced large variations from a minimum of 60,4 thousand in ' 48 to over 6 times in '92, so that at the last census to decrease to 267,1 thousand people. Unfortunately, even the most optimistic scenarios do not lead to positive county population projections.

\section{Changes in the population structure}

Massive population decreases between the last two censuses not occurred evenly across age, sex and areas; this worsening the imbalance that was already taking shape in the 2002 census. 


\subsection{Changes in age structure, sex and life}

Decrease in the population has been primarily done in the detriment of the ages that are part of the workforce, which correlated with a decrease in birth rates have led to an aging population with long-term effects for the generations who will be retiring.

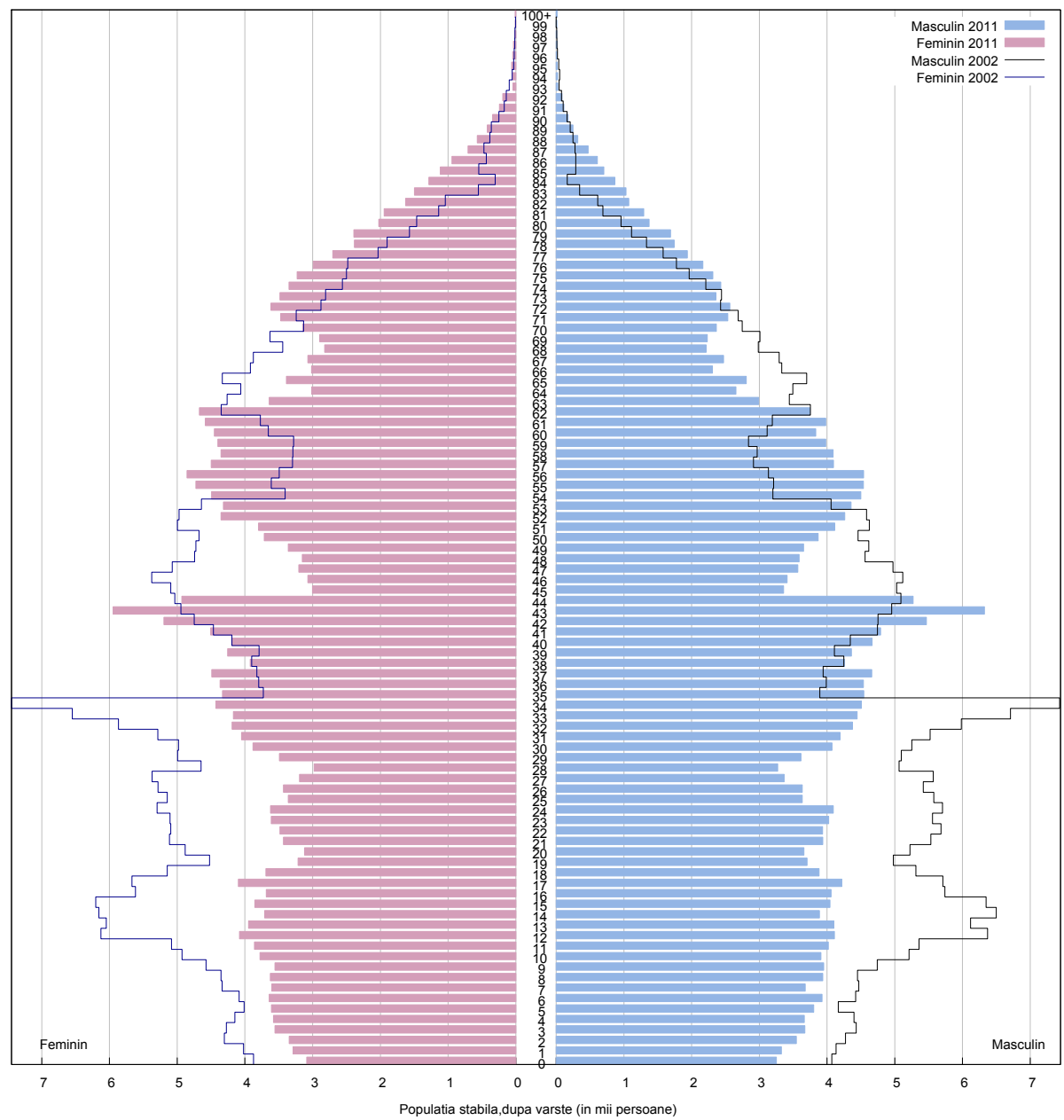

Figure 2 The last two census age pyramid, Bacău county

Source: own calculations based on data from the Statistics Institute of Bacău County

Overlap on the same graph of the age pyramid from the last two censuses in Figure 2 is particularly relevant for the statements above. Massive loss of effective population aged 0-35 years, and on the other hand, increasing the workforce aged over 53 years, have narrowed the bottom of the pyramid, making it very fragile in terms of population, with social-economic consequences if we think of the few who will soon have to support an inactive population (children and elderly) becoming more numerous. 


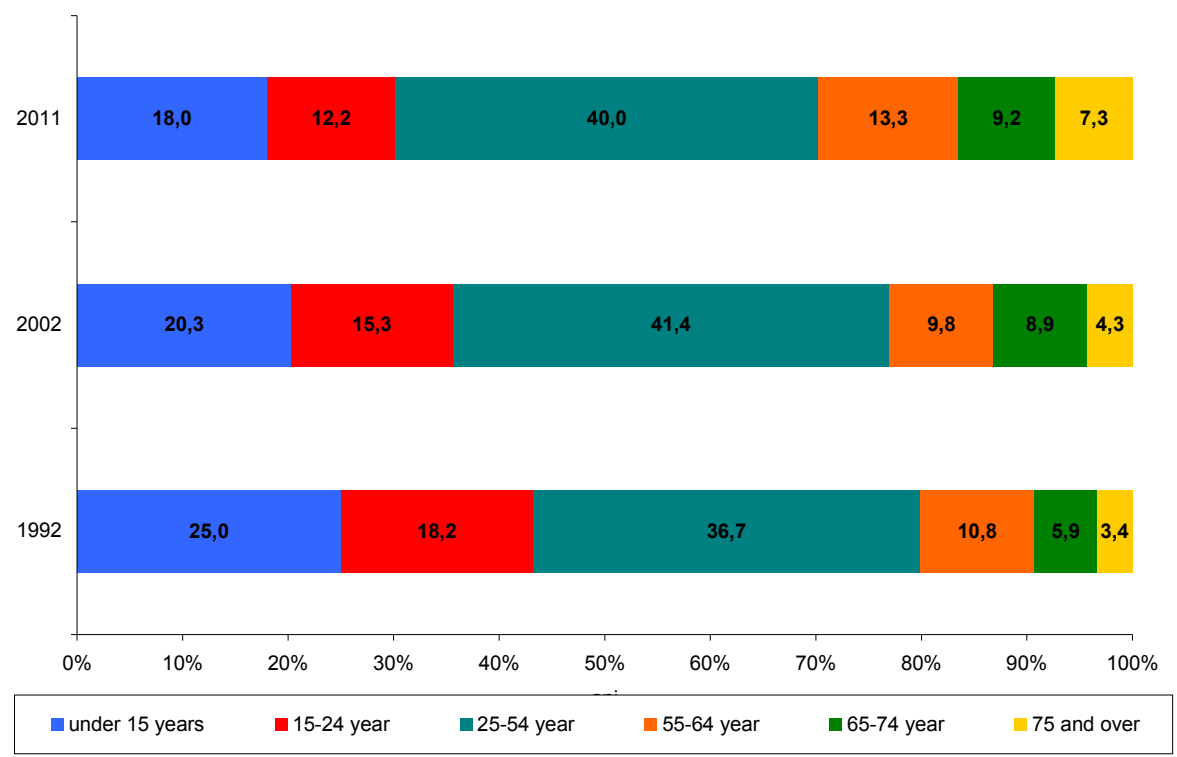

Figure 3 Structure of the population by big groups of aging at the last 3 census Source: own calculations based on data from the Statistics Institute of Bacău County

The effect of changes in age structure as can be seen in Figure 3. If at the census of 1992 the group of under 20 years represented $34,3 \%$ of the total population, it fell to $24,3 \%$ in 2011 , while the group of 65 and over increased from $9,3 \%$ to $16,5 \%$.

Demographic aging of the population is observed in the development of specific indicators such as the rate of population aging and demographic dependency ratio for adults. Thus, in Bacău came back in 1992 a number of 372 elders (65 and over), on average at every 1000 young people (under 15), and in 2011 the index increased 2,5 times, averaging 916 elders at 1000 youngsters. Similarly, if in 1992 came back in average 142 elders at 1000 elderly people (15-64 years), the index reached 2011 the level of $252 \%$.

The same phenomenon can be seen if we compare the evolution in time of the average age of Bacău county population, shown in Figure 4. From an average age of 36,5 years in the 1992 census, it reached 40,2 years in 2011, registering in less than 10 years an increase by 3,7 years. Contrary to expectations, the population is more elder in urban than in rural areas, the average age being 40,9 years in urban and 39,7 years in rural areas, largely due to a higher birth rate in rural areas.

Aging phenomena was more pronounced throughout the city, where the average age between the two censuses has increased by 5,1 years, while in rural areas it increased by 2,6 years. Compared to the national average, the average age is lower in total in Bacău by 0,4 years, but is higher by 0,6 years in urban areas. At the country level, the situation is contrary to Bacău county, the population being aged in rural than in urban areas. 


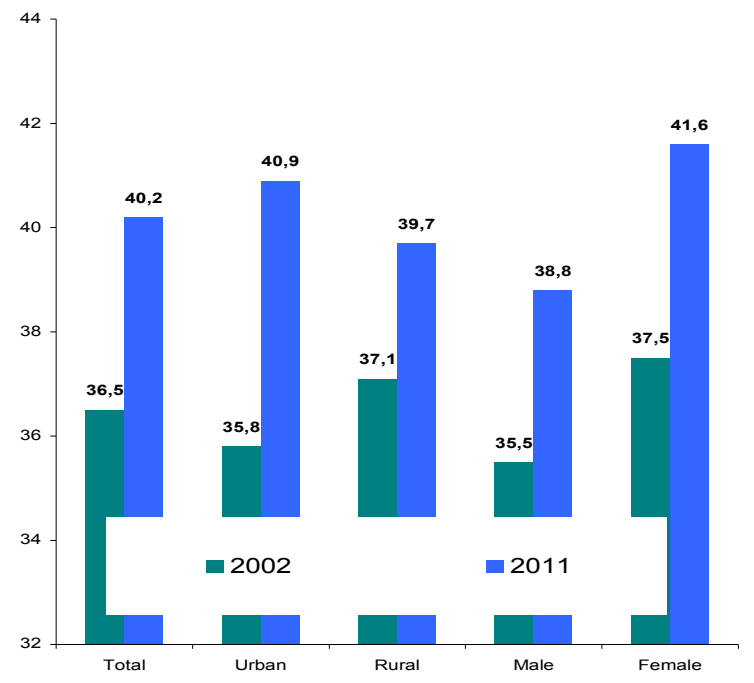

Figure 4 The average age of the stable population in the last two censuses of Bacău County, by area and sex

Source: own calculations based on data from the Statistics Institute of Bacău County

Aging phenomena has increased even more for women than men. Thus, for women, the average age increased in about 10 years by 4,1 years, reaching 41,6 years in 2011 as compared with 38,8 years for men and an addition of only 3,3 years. In both sexes the national average age is higher than the county of Bacău.

If you could compare the two age pyramids, it will be found that in rural areas there is the greatest imbalance by age and sex. Both the rural bottom and top of the pyramid are large compared to the middle, that actually forms the active workforce and financially support both base and top, respectively the children through their allocations and the elderly with the pensions and social benefits they receive.

The imbalance in rural areas is grater than in urban areas and in terms of population structure by sex. In rural men outnumber women at most ages groups under 55, the largest discrepancy being groups $19-25$ years (by $-10 \%$ up to $-17 \%$ ) and $37-52$ years (with differences ranging between $10 \%$ and $30 \%$ ) groups in the active population, while for the group of more than 56 years, the women surpass men numerically except the age of 99 and 100 years. Migration of a massive segment of the working age of female population in the urban areas, it can be seen if we compare the two pyramids. In urban areas, in all age groups between 34 and 97 years, women exceed men numerically .

\subsection{Changes in ethnic and confessional structure}

At the census of 2011, due to the absence from home of a large number of people, for those who could not declare the neighbors, the information was retrieved from administrative sources, which made for these people not to be possible to be declared the ethnicity, language tongue and religion. This is also the case of those for whom information was reported by neighbors, relatives, acquaintances and according to the methodology were not allowed to respond to these "sensitive" variables on behalf of those for whom they responded. Thus, for Bacău data was collected about ethnicity by free statement from a total of 579.580 people out of a total of 616.168 , which leaves a percentage of $5,94 \%$ of the total for which the ethnicity is unknown. For this reason, 
for better comparability with the 2002 census population structure, it has been calculated only for a total of 579.580 people who answered the question.

The majority population at the last census had Romanian nationality, numbering 558.507 people, accounting for $96,36 \%$ of the total. There was declared a total of 15.284 Roma people $(2,64 \%$ of total), a total of 4.208 Hungarian people $(0,73 \%$ of total). The many Roma communities are in: Corbasca, Valea Seacă, Buhuşi, Bacău, Moineşti, Dărmăneşti, Ştefan cel Mare, Blăgeşti, Buciumi, Coţofăneşti, Comăneşti, Parava, Berzunţi, Gura Văii and Livezi, in the other areas being below 200 people. The most numerous communities of Hungarians, over 100 people, in descending order are found in the following localities: Ghimeş-Făget, Răcăciuni, Agăş, Pârjol, Cleja and Bacău.There were also declared 829 Csangos, 99 Germans, 91 Italians, 51 Turks, the other ethnic groups having a small number of people in the county.

Compared to the previous census, the share of Roma increased in total from $1,68 \%$ to $2,64 \%$, while the share of Romanians decreased from $97,47 \%$ to $96,36 \%$. Romanian decrease in weight was certainly influenced by the fact that probably most of the people for whom data were collected from other sources (neighbors, relatives, or administrative) and the ethnicity could not be recorded, were Romanian . Same issue also with the declared religion. A total of 470.560 people declared their religion as the orthodox $(81,22 \%$ of the total people declared ), 96.490 people roman catholics $(16.65 \%), 5.492$ people with pentecostal religion $(0,95 \%)$, other denominations with a much smaller share in total. The most numerous communities of the roman catholic religion (between 12,5 thousand people and 2 thousand) are in the following localities: Bacău, Cleja, Nicolae Bălcescu, Oituz, Mărgineni, Pârgăreşti, Faraoani, Oneşti, Răcăciuni, Gârleni, Luizi-Călugăra, Târgu-Trotuş, Ghimeş-Făget, SlănicMoldova and Gioseni.

\subsection{Changes in population structure by marital status}

At the last census, in Bacău there were a number of 237.303 single people, of which $56,3 \%$ were male and $43,7 \%$ female. Legally married were a number of 147.058 men and 148.529 women and 11.713 men and 13.884 women were divorced. A total of 11.655 men were widowed, while widows were almost 4 times as many (45.947 people), the result of a higher average lifespan in women than in men. In consensual union (cohabiting), there were 20.126 people that lived at the time of the census, accounting for $3,3 \%$ of the total stable population. Compared with the population structure by marital status at the national level, there are not significant diferences at county level.

In the county, between the two censuses, major changes occurred in the structure of the segment of the widow population, that share grew from $3,4 \%$ in 2002 to $9,35 \%$ in 2011, and also a decrease in the share of people divorced, and a slight decline in the married population. Changes in structure between the two censuses can be seen easily in Figure 5.

Increase by $75,6 \%$ is seen in the number of people who declared they live in a consensual union, from 11.460 people at the 2002 census, reaching 20.126 people in October 2011. This phenomenon is common at country level, the average age at marriage experiencing an increase in recent years, partly because of the increasing cost of living and of unemployment, which makes many young people to postpone marriage until they build a stable situation from a financial point of view. On the other hand due to the emancipation of women, who increasingly prefer to become more financially independent from man and want to make a career first at the expense of family life. 

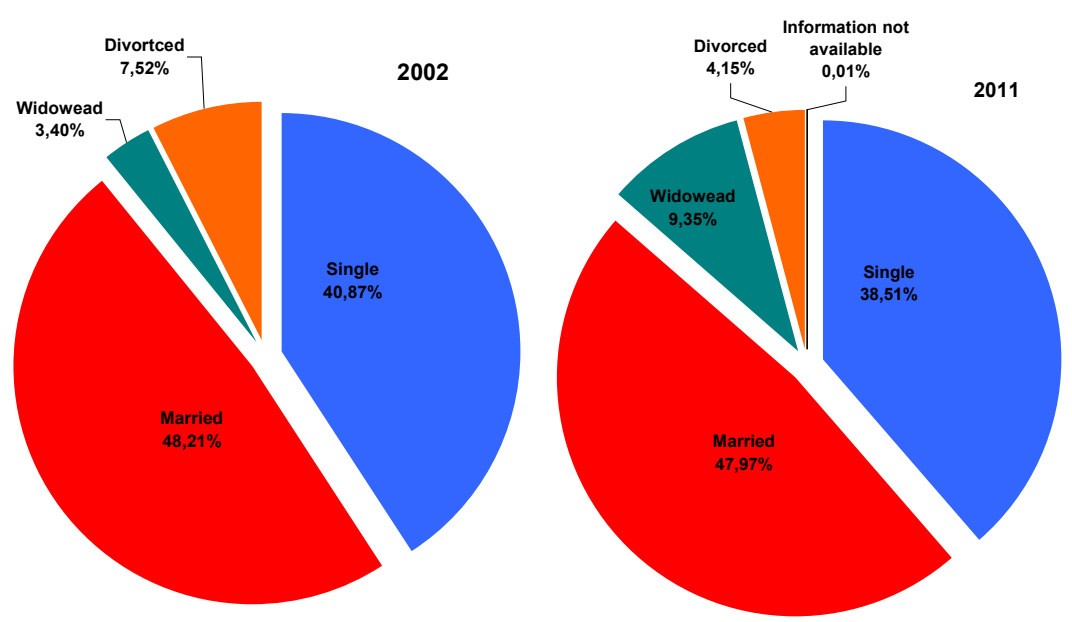

Figure 5 Stable population structure by marital status of Bacău County, in the last two censuses

Source: own calculations based on data from the Statistics Institute of Bacău County

From a total of unmarried people, $60,3 \%$ were living in urban areas and from a total of married people, 53,9\% were from urban areas. Of the total widowed, $61,9 \%$ were from urban and from divorced persons in total, most were living in rural $(56,9 \%)$.

\subsection{Changes in population structure by education level}

At the 2011 census, a total of 544.535 people in the county were aged 10 years and over, therefore they should have completed at least primary level education for 4 years. From this group, most had completed secondary school (155.383 people), followed by upper secondary school (208.629 persons, of which 105.090 high school graduate and 103.539 professional school and apprenticeship), primary school ( 88.953 persons), while higher education had a number of 55.431 people. As can be seen from Figure 6, between the two censuses, changes in the stable population by educational level were in favor of a higher level of education, respectively an increase in the share of higher and secondary education level.Although the number of those who graduated increased from 31.611 people in 2002 to 55.431 people in 2011, compared with the structure at national level, Bacău county still has a smaller percentage: $14,38 \%$ at national level and $10,18 \%$ in Bacău. The same aspect is recorded at high school level, Bacău has a share of 19,3\% from the total, while the national average is $24,36 \%$. Instead, the primary level of education is found in Bacău at $16,34 \%$ of the people, and at national level at $14,18 \%$ of people of 10 years and older.

On October 20, 2011 there were in the county a number of 19.306 people who were graduates of any school, although they were at the age at which they were supposed to be primary school graduates, of whom a number of 8.806 being illiterate, mostly women. 


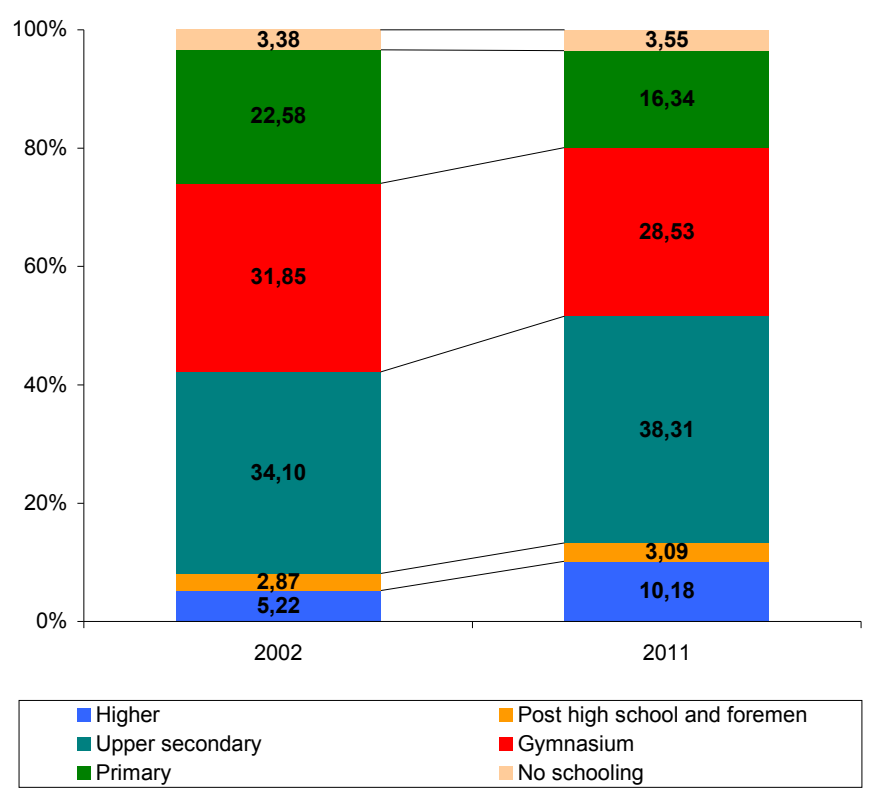

Figure 6 Structure of stable population of 10 years and over after the last school graduated, the last two censuses

Source: own calculations based on data from the Statistics Institute of Bacău County

The share of those with no school degree was higher in Bacău $(3,55 \%)$ than the national level $(3 \%)$, as in the case of illiterates $(1,36 \%$ national level while $1,62 \%$ county level). Of those described above, it results that although the level of education increased in Bacău, we are still below the average of the country.

There are also in the case of educational level discrepancies between the two environments for a better education in urban areas and lower in rural. Thus, if from the total population of 10 years and over in urban, 19,11\% were educated to the last census, in the rural only $3,16 \%$ had this level of training. The same happens in the case of upper secondary, the urban share being $27,64 \%$ and only $12,75 \%$ in rural areas. An opposite situation is observed at the low level of education: the rural $36,2 \%$ had secondary education compared to $18,77 \%$ in urban, $21,78 \%$ from rural population had primary level of education compared to $9,4 \%$ in urban areas, $4,76 \%$ had no schooling in rural compared to $1,99 \%$ in urban or in rural areas the illiterate were $2,26 \%$ to $0,8 \%$ in urban areas. The highest percentage of population with no schooling are found in older age groups $(10,07 \%$ at 75 years and over and $4,96 \%$ at $70-74$ years), but unfortunately there is also a share of $16,94 \%$ at the age group of 10 14 years, where the conclusion of a high school dropout or repetition of classes in elementary school.

\section{Conclusions}

If until in the '90s the trend of population growth was due to a positive natural growth and stability in terms of migration, after this year things got somehow out of control. On one hand, the increasing number of less live births led to a decrease in natural way and, on the other hand illegal migration at the beginning, and after joining the EU somehow becoming legal, made possible to lose significant shares of population. 
Bacău County experienced the last two censuses the largest absolute reduction in stable population among the country. Located in the poorest region in the country, in a county with a strong industry that attracted the majority of the workforce, this started losing each year population as a result of massive layoffs in the industry, the impact on unemployment and poverty. These latter aspects determined much of the population to leave to rural areas on the one hand, where one could live with less cost and therefore this reversed the share of the population for the two areas in favor of the rural areas. On the other hand people preferred to migrate to countries that offered them a job. At the last census, there were declared by the family and neighbors a number of over 57 thousand people as traveling to other countries for a long time (over a year), and have not been included in the population of the county. Of these, $73 \%$ were at work in Italy, 7,62\% in the UK and 7,5\% in Spain. But, besides these, there was a large enough number for which there was no one to declare to the census, therefore, the number of those who left is much higher, which led to a decrease by more than $18 \%$ of the county population. Moreover, the migration of the population occurred in a higher proportion at the working age groups, especially between 20-44 years, taking with them over 5.000 children under 15 years who left after parents in other states. This led to greater imbalances by age, which could be observed by comparing the two pyramids of age.

Urban population decline $(-18,1 \%)$ occurred in a higher proportion than in rural areas $(-8,2 \%)$ between the last two censuses, compared with the national average where the decrease felt stronger in rural than in urban. This led to the widening of the imbalances by areas, being more highlighted a higher share of the rural in Bacău $(56,6 \%$ compared to the national average of $46 \%)$. In fact, if from the total stable population reduction in the country between the last two censuses was due of $37 \%$ to urban, in Bacău the overall reduction was due to the urban in a share of $65,4 \%$. Regarding education, even if it increased in the last census, we have shown that we are still under the national average, primarily due to the higher degree of poverty throughout the area.

In conclusion, compared to other areas of the country, much larger investments are needed to reduce the gap in the development of the counties, which would lead to the creation of jobs and attracting people who migrated, or even to preserve those that remain, and economic development would lead to better investment in education, with long-term effects.

\section{References}

Barthelemy, P, Granier, B, Robert, M, (2009), Demografie şi societate, Bucureşti, Institutul European.

Harja, E, (2004), Analiza şi prognoza statistică a numărului şi structurii forţei de muncă, Bucureşti, Ed. MatrixRom.

Harja, E, (2009), Statistică şi econometrie, Bacău, Ed. AlmaMater.

Sora, V., Mihăescu, C., Colibabă, D., Grădinaru, G., Danciu, A. (2002), Analiză statistică demografică. Teorie şi aplicaţii, Ed. Economică.

Statistical data from Statistics Institute of Bacău County, available on http://www.bacau.insse.ro/main.php, http://www.bacau.insse.ro/phpfiles/ Comunicat_rezultate_definitive_RPL_2011_judet\%20Bacau.pdf.

Stoica, I, (2011), Tentaţia migratiei. Necesitate şi oportunitate intr-o lume globalizată, Ed. Militară. 